\title{
Toxic effects of Drimia maritima (Asparagaceae) ethanolic extracts on the mortality, development, sexual behaviour and oviposition behaviour of Drosophila melanogaster (Diptera: Drosophilidae)
}

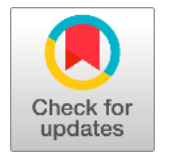

\author{
Fatma Zohra Saadane $^{\text {a* }}$ (D) | Wafa Habbachi ${ }^{\text {(iD }}$ | Sarra Habbachi ${ }^{\text {(iD }}$ | Nour El Imene Boublata ${ }^{\text {(iD }}$ | \\ Abderachid Slimani $^{\mathrm{b}}$ | Abdelkrim Tahraoui ${ }^{\mathrm{a}}$
}

Applied Neuroendocrinology Laboratory. Department of Biology, Faculty of Sciences, University Badji Mokhtar Annaba 23000, Algeria.

Department of Biology, Faculty of Science, University Badji Mokhtar BP 12, 23000 Annaba, Algeria.

Corresponding author: saadanezahra2@gmail.com

\begin{abstract}
Drimia maritima is a toxic Mediterranean plant and is considered a commercially important drug by its medicinal values and pharmacological properties. In this work, we seek to evaluate the direct and delayed effects of the ethanol extracts of this plant on vinegar fly (Drosophila melanogaster), an excellent laboratory model. The treatment was carried out by ingestion on second-stage larvae (L2) and then we evaluated the impact of this treatment on mortality, development, sexual behaviour, on female's oviposition choice, fecundity, and fertility of adults. The results showed that mortality rates can reach $100 \%$ after 15 days of treatment as we recorded an acceleration of the flies' development. After treatment, we observed incomplete nuptial courtship and a significant decrease in eggs laid number and larvae number of the first generation treated. This study indicates that $D$. maritima ethanolic extract has a neurotoxic property, our results confirmed the presence of toxic secondary metabolites in the extract studied.
\end{abstract}

Keywords fruit fly, mating, Mediterranean plant, reproduction, toxicity

\section{Introduction}

In recent years, natural products have drawn the researchers' attention to find new solutions alternatives where the aims are to reduce the excessive use of synthetic pesticides. Among these alternatives in nature, products of plant origin are, in particular, more interesting because they are less toxic, biodegradable, and target-specific (Dua et al 2010; Subramaniam et al 2012).

Recently, the plant extracts with insecticidal properties have continued to develop and some nonEuropean countries have regulatory requirements for extracts and essential oils use (Isman 2019). Plants are rich in bioactive secondary chemical metabolites and have proven their insecticidal activity by killing or repelling insects (Sukumar et al 1991; Ghosh et al 2012).

Medicinal plants are valuable resources for the majority of rural and urban populations in Africa and are the main means by which people treat themselves (Badiaga 2011). Several species are known for their remarkable therapeutic properties (Quezel 1978). Algeria, by the richness and diversity of its flora, constitutes a real phylogenetic reservoir, with about 4000 species and subspecies of vascular plants (Dobignard and Chatelain 2013). The study of traditional medicine and herbal treatment is therefore of particular interest because little research has been done on this aspect, and more particularly on the use of spontaneous species in traditional medicine (Hammiche and Gueyouche 1988).

Our study is based on the medicinal plant Drimia maritima which is very widespread in the Mediterranean region, Africa and India their medicinal part is mainly composed of fresh or dried bulbs (Ghahreman 1997; Zargari 1996). The oldest writings on these plants date back to 1500 B.C. and mention the medicinal Drimia properties (Stoll 1954). To date, many studies have been conducted to identify the chemical constituents and to understand the pharmacological properties of this species.

It is a Mediterranean plant, perennial by an enormous bulb whose diameter reaches, 20 to $30 \mathrm{~cm}$ and weight between 5 to $7 \mathrm{~kg}$ (measures of Algerian species). It's formed of nested scales that are also called tunics or scales, whitish color called Scille d'Italie or Scille "female" or reddish Scille d'Espagne or Scille "male", depending on the variety. The external scales are plain and membranous, the medium scales are thick and fleshy (Hammiche et al 2013). The flowering stem (about $1 \mathrm{~m}$ ) bears at its end a cluster of small white flowers with a star-shaped corolla (Joly 2010).

This work purpose to test the direct and indirect toxic effects of $D$. maritima ethanolic extract on fruit fly, Drosophila melanogaster, especially, the effects on the mortality, development, sexual, and oviposition behaviour. 
D. melanogaster, the world's most widely distributed species, is considered a dreaded nuisance both for the inconvenience caused by the parasitic diseases it can inoculate (Jolivet 1980; Joly 2006; Habbachi et al 2013). It is also an important vector for various infectious microorganisms, including phytopathogenic yeasts and bacteria that attack not only vegetable and fruit crops but also cereal and sunflower crops (Kloepper et al 1979; Corby-Harris et al 2007; Nadarasah and Stavrinides 2011; Becher et al 2012).

\section{Materials and Methods}

\subsection{Elevage des insects}

Drosophila melanogaster was described by Johann Wihelm Meigen in 1830. Its reproduction is very fast. Its life cycle is very short and includes three larval instars and a pupal stage from which an adult emerges that can fly and reproduce. A wild strain harvested from rotten apples in Annaba region (Algeria), was used. The culture was carried out in vials $(250 \mathrm{ml})$ capped with a foam pad and containing an agar-based nutrient medium of cornmeal and brewer's yeast. The culture was maintained at $25 \pm 1{ }^{\circ} \mathrm{C}$, a humidity of 70 to $80 \%$, and a 12-hour scotophase.

\subsection{Drimia maritima (Asparagaceae)}

It is a bulbous plant, which grows in the Mediterranean region. The main properties of this plant considered in traditional medicine are dropsy, cough and respiratory diseases, jaundice, skin problems, leprosy, baldness, gastric disorders, cancer, epilepsy, joint pain, and use as an antidote (Stannard 1974; Aliotta et al 2004). The $D$. maritima bulbs had significant insecticidal activity against several species (Pascual-Villalobos and Fernandez 1999; Metin and Burun 2010). For the present study the plant is collected in the region of Seraïdi (Annaba, Algeria) (36 $54^{\prime} 27.02^{\prime \prime}$ north latitude, $7^{\circ} 39^{\prime} 49.95^{\prime \prime}$ east longitude).

\subsection{Preparation of the ethanolic extract of D. maritima}

For the extract, we macerated the dry bulb powder $(300 \mathrm{~g})$ in ethanol $(250 \mathrm{ml}$ at $70 \%)$ for 24 hours in laboratory conditions and on the shade. After filtration using Whatman filter paper, the liquid obtained was evaporated using a magnetic stirrer heated to $45^{\circ} \mathrm{C}$ to remove ethanol. The $10 \mathrm{~g}$ leg recovered was stored at $4{ }^{\circ} \mathrm{C}$ until use.

\subsection{Treatment of larvae with D. maritima extract}

We prepared three different concentrations 0.12 $\mu \mathrm{g} / \mathrm{ml}, 0.25 \mu \mathrm{g} / \mathrm{ml}$, and $0.5 \mu \mathrm{g} / \mathrm{ml}$. The treatment is done by ingestion; each concentration is mixed with food $(40 \mathrm{~g})$ which will be distributed in four different tubes. In these tubes, 20second instar larvae (L2) from the mass rearing are placed. In a fifth tube containing no treatment, 20 larvae are placed as a control. The monitoring of mortality and larval development is done for 15 days (time needed to finish development).

\subsection{Effect of the plant extract on sexual behaviour}

Sexual parade in fruit flies is an eventful behavior (Clynen et al 2011; Chardonnet 2013), goes through six essential, predetermined and invariable steps (Terhzaz 2003; Dickson 2008; Revadi et al 2015) and requires many sensory signals, of which chemical signals (cubic hydrocarbon pheromones) play an important role (Greenspan and Ferveur 2000; Sokolowski 2001). The male first walks up to a potential female and taps her on the cuticle with his front legs; if the female moves, the male follows and vibrates a wing. Then, when the female stops, the male runs in circles around her, lick her genitals with his proboscis, and tries to hang her up until mating (Revadi et al 2015).

In this work, we treated the larvae group with the sublethal concentration of $D$. maritima extract $(0.12 \mu \mathrm{g} / \mathrm{ml})$ and then recovered the adults as soon as they emerged. 48 hours after emergence, these adults were used for sexual behaviour tests where we note the time and number of contacts, the time and number of wing vibrations, the time and number of licks, the time and number of mating attempts as well as the time and duration of mating if successful. These tests are carried out according to four types of crossings: control male $X$ control female, treated male $X$ treated female, control male $X$ treated female and treated male $X$ control female.

\subsection{Effect of the plant extract on oviposition behaviour and reproduction:}

To the purpose of determining the egg-laying site choice, we observed mated females and we noted the site eggs hatching, as well as eggs and larval numbers.

\subsection{Data analysis}

The toxicological parameters (LC50\%, LC90\%, LT50\%, and LT90\%) were calculated according to Finney's mathematical methods (Finney 1971). Regarding sexual and oviposition behavior tests, results were analyzed statistically by descriptive metric methods then an analysis of variance (ANOVA) was performed on XLSTAT 2009 software (Addinsoft, New York, NY).

\section{Results}

\subsection{Effect on mortality and development}

The results showed that D.maritima ethanol extracts act on the duration of larval development and larval mortality depending on the concentration applied. The three concentrations used showed high larvicidal activity at the end of mortality monitoring (15 days after treatment) (Table 1); and $100 \%$ of the population was killed after 15 days of treatment (Table 1). There are very highly significant differences between the mortality rates recorded as a function of concentrations and exposure times $(P=0.001 ; P$ $=0.003 ; P=0.000$ ) (Table 1). 
Table 1 Insecticidal effects of $D$. maritima on $D$. melanogaster.

\begin{tabular}{|c|c|c|c|c|c|}
\hline & $0.12 \mu \mathrm{g} / \mathrm{ml}$ & $0.25 \mu \mathrm{g} / \mathrm{ml}$ & $0.5 \mu \mathrm{g} / \mathrm{ml}$ & $\mathrm{F}_{\mathrm{obs}}$ & $P$ \\
\hline 2 days & $0 \%$ & $0 \%$ & $0 \%$ & - & - \\
\hline 5 days & $0 \%$ & $0 \%$ & $0 \%$ & - & - \\
\hline 10 days & $10 \%$ & $13.75 \%$ & $13.75 \%$ & 2.37 & $0.000 * * *$ \\
\hline 15 days & $100 \%$ & $100 \%$ & $100 \%$ & - & - \\
\hline$F_{\text {obs }}$ & 10.99 & 8.37 & 16.40 & & \\
\hline$P$ & $0.001 * * *$ & $0.003^{* *}$ & $0.000 * * *$ & & \\
\hline
\end{tabular}

D. maritima had a significant effect on fly development by inducing acceleration in larvae growth to pupae, at all three concentrations. For the adult stage, an activity on development was recorded; only $80 \%$ of the treated population with ethanolic extracts of $D$. maritima reaches the adult stage (Figure 1 ).
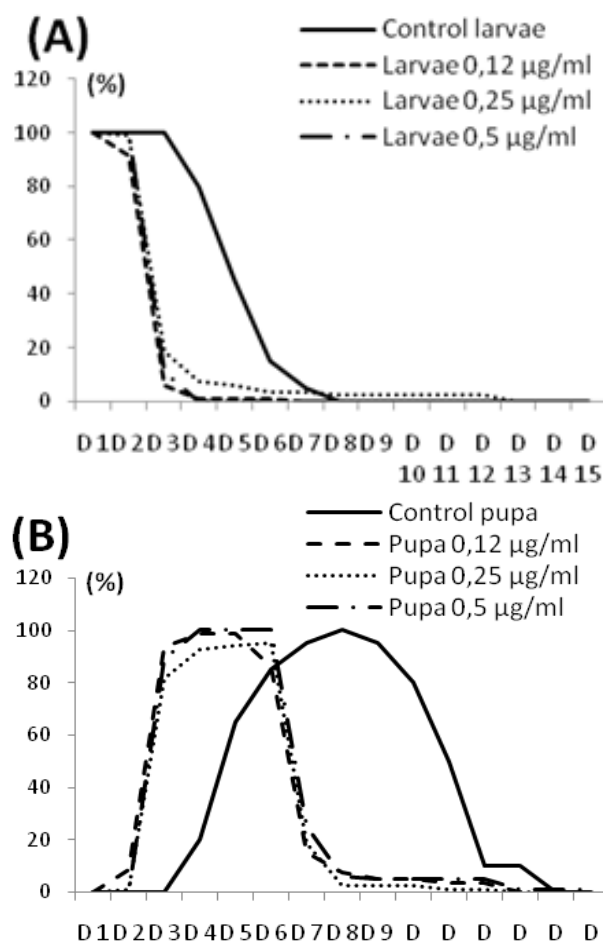

101112131415

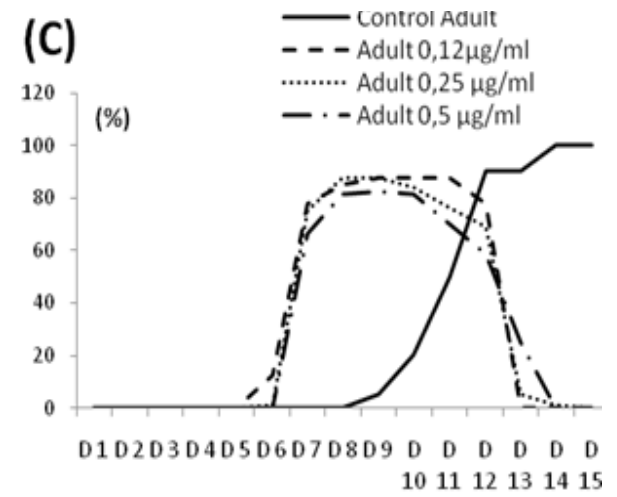

Figure 1 Effect of $D$. maritima ethanolic extract on $D$. melanogaster development (A: Larval development; B: Pupal development; C: Adult development).
Larval mortality rates were strongly and positively correlated with the extract concentrations used (Table 2A). The $50 \%$ lethal concentration reaches $0.35 \mu \mathrm{g} / \mathrm{ml}$ at 10 days of exposure (Table 2A). $90 \%$ of larvae die with $1.25 \mu \mathrm{g} / \mathrm{ml}$ concentration after 10 days (Table $2 \mathrm{~A}$ ).

For lethal times, the results showed that there is a strong positive correlation between mortality rate and exposure time of larvae to the plant extracts (Table 2B). Our results indicate that TL50\% was 10.79 days for the low concentration $(0.12 \mu \mathrm{g} / \mathrm{ml})$ and 9.33 days for both concentrations $(0.25$ and $0.5 \mu \mathrm{g} / \mathrm{ml})$. TL90\% reaches 12.88 days for the highest concentration (Table 2B).

\subsection{Effect on the sexual behaviour of D. melanogaster}

\subsubsection{Effect on mating success rate}

The results showed that $D$. maritima ethanolic extract administered at a sublethal concentration $(0.12 \mu \mathrm{g} / \mathrm{ml})$ decreases the successful mating rate in the fly regardless treated sex within a couple (dyad) (Table 3). The mating success rate was $100 \%$ in controls, whereas it reaches $20 \%$ when one partner was treated with the Mediterranean plant (Table 3 ). The aborted mating rate (couples attempting to mate unsuccessfully) was $20-30 \%$ while the null mating number (neither attempt nor mating) was higher in treated couples (Table 3).

\subsubsection{Effect on nuptial courtship and mating}

We have recorded that treated couples (composed of treated males and females) take less time to establish the first contact between partners. The study showed that there are highly significant differences between the time of this mutual recognition $\left(\mathrm{F}_{\mathrm{obs}}=5.811 ; P=0.001^{* *}\right.$ ) (Table 4). The same result was observed at different times recorded during the nuptial $D$. menlanogaster courtship (first vibration time $P$ $=0.006^{* *}$; first licking time $P<0.0001^{* * *}$; first attempt time $P=0.012$; mating duration $P=0.008^{* *}$ ) (Table 4).

The $D$. maritima plant extract had a significant influence on the flies contacts number $\left(\mathrm{F}_{\mathrm{obs}}=9.136 ; P<\right.$ $\left.0.0001^{* *}\right)$, on wing vibrations number $\left(\mathrm{F}_{\mathrm{obs}}=9.631 ; P=\right.$ $\left.<0.0001^{* * *}\right)$ and licking number $\left(\mathrm{F}_{\mathrm{obs}}=10.091 ; P<0.0001^{* * *}\right)$ (Table 4). 
Table 2 Toxicological parameters of $D$. maritima ethanolic extracts on $D$. melanogaster

A

\begin{tabular}{|c|c|c|c|c|c|c|c|c|c|}
\hline & Regression & CL50\% & CL90\% & CL84\% & CL16\% & SLOPE & $\int \mathrm{cl} 50 \%$ & Low.lim & Up.lim \\
\hline 10 Days & $Y=6.05+2.29 X\left(R^{2}=0.87\right)$ & 0.35 & 1.25 & 0.95 & 0.12 & 2.82 & 1.20 & 0.291 & 0.421 \\
\hline \multicolumn{10}{|c|}{ B } \\
\hline & Regression & $\mathrm{TL}_{50 \%}$ & $\mathrm{TL}_{90 \%}$ & TL84\% & TL16\% & SLOPE & STI50\% & Low.lim & Up.lim \\
\hline $0.12 \mu \mathrm{g} / \mathrm{ml}$ & $Y=-3.98+8.72 X\left(R^{2}=0.87\right)$ & 10.79 & 14.79 & 13.8 & 8.12 & 1.30 & 1.049 & 10.29 & 11.31 \\
\hline $0.25 \mu \mathrm{g} / \mathrm{ml}$ & $Y=-4.14+9.37 X\left(R^{2}=0.90\right)$ & 9.33 & 12.88 & 12.02 & 7.24 & 1.29 & 1.046 & 8.92 & 9.76 \\
\hline $0.5 \mu \mathrm{g} / \mathrm{ml}$ & $Y=-4.14+9.37 X\left(R^{2}=0.90\right)$ & 9.33 & 12.88 & 12.02 & 7.24 & 1.29 & 1.046 & 8.92 & 9.76 \\
\hline
\end{tabular}

A: larval exposure time, B: concentrations used, $y$ : probits of mortality rates, $X$ : the decimal logarithm of concentrations and/or times.

Table 3 D. maritima $(0.12 \mu \mathrm{g} / \mathrm{ml})$ effects on successful mating rate.

\begin{tabular}{cccc}
\hline & \multicolumn{3}{c}{$\%$ mating } \\
\cline { 2 - 4 } & Successful & aborted & null \\
\hline$\sigma^{\top} C \times \$ C$ & 100 & 0 & 0 \\
\hline$\sigma^{\prime} C \times \$ D . m$ & 20 & 20 & 60 \\
\hline$\sigma^{x} D . m \times \$ C$ & 20 & 25 & 55 \\
\hline$\sigma^{\prime} D . m \times \$ D . m$ & 40 & 30 & 30 \\
\hline C: Control; D.m: Treated with D. maritima ethanolic extract
\end{tabular}

Table 4 Effect of $D$. maritima ethanolic extracts on the different sexual behaviour sequences (Mean \pm SEM).

\begin{tabular}{|c|c|c|c|c|c|}
\hline & First contact time & First vibration time & First licking time & First attempt time & Mating time \\
\hline$\sigma^{2} \mathrm{C} \times P C$ & $201.150 \pm 30.910$ & $211.150 \pm 31.177$ & $284.450 \pm 33.620$ & $302.500 \pm 36.337$ & $485.150 \pm 64.382$ \\
\hline$\sigma^{\prime} D . m \times 9 D . m$ & $136.900 \pm 50.275$ & $262.000 \pm 86.472$ & $270.550 \pm 97.666$ & $307.450 \pm 108.753$ & $91.650 \pm 31.746$ \\
\hline$\sigma^{\prime} \mathrm{C} \times 9 D . m$ & $296.900 \pm 77.392$ & $509.350 \pm 98.319$ & $471.550 \pm 135.753$ & $245.700 \pm 102.638$ & $122.600 \pm 68.954$ \\
\hline$\sigma^{\prime} D \cdot m \times q C$ & $229.950 \pm 57.129$ & $293.150 \pm 64.218$ & $353.250 \pm 98.629$ & $156.950 \pm 67.466$ & $122.750 \pm 62.777$ \\
\hline $\mathrm{F}_{\text {obs }}$ & 5.811 & 4.550 & 9.200 & 3.925 & 1.155 \\
\hline \multirow[t]{2}{*}{$P$} & $0.001 * *$ & $0.006^{* *}$ & $<0.0001^{* * *}$ & $0.012^{*}$ & 0.333 \\
\hline & Contacts number & Vibrations number & Licking number & Attempts number & Mating duration \\
\hline$\sigma^{2} \mathrm{C} \times P C$ & $3.000 \pm 0.653$ & $14.050 \pm 2.929$ & $3.150 \pm 0.499$ & $3.200 \pm 0.506$ & $1058.100 \pm 93.620$ \\
\hline$o^{\prime} D . m \times 9 D . m$ & $4.100 \pm 1.367$ & $11.150 \pm 3.081$ & $4.150 \pm 1.418$ & $2.400 \pm 1.278$ & $63.000 \pm 25.795$ \\
\hline$\sigma^{\prime} \mathrm{C} \times 9 D . m$ & $0.950 \pm 0.223$ & $4.700 \pm 1.124$ & $1.550 \pm 0.478$ & $0.550 \pm 0.198$ & $131.600 \pm 69.363$ \\
\hline$\sigma^{\prime} D \cdot m \times q C$ & $1.300 \pm 0.411$ & $3,400 \pm 1,473$ & $1.000 \pm 0.370$ & $0.450 \pm 0.223$ & $129.050 \pm 69.252$ \\
\hline $\mathrm{F}_{\mathrm{obs}}$ & 9.136 & 9.631 & 10.091 & 3.975 & 4.222 \\
\hline$P$ & $<0.0001^{* * *}$ & $<0,0001 * * *$ & $<0.0001^{* * *}$ & 0.011 & $0.008^{* *}$ \\
\hline
\end{tabular}

Mean: Mean; SEM: Standard deviation of the mean; C: Control; D.m: Treated with D.maritima ethanolic extract $P<0.05^{*}$ : significant; $P<0.01^{* *}$ : highly significant $P<0.001^{* * *}$ : very highly significant

The follow-up of 20 mated females for different crosses types allowed us to determine the laying choice, fertility, and fecundity of flies after treatment.

The results in Table 5 show that the eggs laid number was low in couples where one of the two partners is treated (about 6 to 9 eggs). This result was subsequently observed in the emerged larvae; the larvae number in these couples was $2.550 \pm 0.933$ larvae to $4.700 \pm 1.659$ larvae (Table 5 ). The eggs laid number in the control and treated medium was the same for all four crosses types $(P \geq 0.05)$.

\subsection{Oviposition Preference Index (OPI)}

Couples with a control female and a treated male prefer the control medium with a negative preference index $(-0.05)$ (Figure 2). The results show that there was a repellent effect of D.maritima ethanolic extract (Figure 2). 
An OPI is zero in control of couples (Figure 2). The treated couples had an OPI of $(+0.02)$ which shows that females of these couples are attractive to the treated medium (Figure 2).

\section{Discussion}

Insect control is entering a new "botanical" phase that provides no-toxic molecules to no-target organisms, biodegradable, less likely to provoke resistance in target species, and appear one of means in better harmony with the environment (Philogene 1991). Natural plant extracts contain a wide variety of secondary metabolites to which various biological and toxicological activities are attributed.

D. maritima, commonly known as "squill", is complex but well studied, because of its cardiac glycoside (medicinal) and raticide activity; but relatively little is known about its insecticidal activities (Civelek and Weintraub 2004). Hassid et al (1976) were the first to examine insecticidal properties of $D$. maritima extracts. They showed that $D$. maritima foliage was highly toxic to lepidopterous larvae, such as Spodoptera littoralis, and methanol extracts of dried leaves (which contained L-azetidine-2-carboxylic acid AZA), when incorporated into the artificial diet, also caused $100 \%$ mortality. Besides, the use of aqueous extracts of pentaploid (n_50) white bulbs from D. maritima and applied these extracts as an insecticide has been used against a tomato pest and has shown treatments reduced the number of larvae to two or fewer per leaf (Civelek and Weintraub 2004).

In this study, we have highlighted the direct and delayed toxicological effects of this Mediterranean plant. The maceration of D.maritima bulbs in ethanol allows the recovery of an extract with high insecticidal activity, causing very high mortality rates in the fruit fly. Fly mortality is mainly a function of exposure time. Other studies show that plant extracts can have an intense insecticidal activity on fruit flies, such as the study of Habbachi et al (2013) when using Peganum harmala (Zygophyllaceae) extracts; this work showed that seed extract caused more mortality compared to $P$. harmala leaves.

Table 5 Effect of D. maritima ethanolic extract on numbers of laid eggs and larvae.

\begin{tabular}{|c|c|c|c|c|c|c|c|c|}
\hline Couples & $\begin{array}{c}\text { Laid eggs } \\
\text { number in } \\
\text { control medium }\end{array}$ & $\begin{array}{c}\text { Laid eggs } \\
\text { number in } \\
\text { Drimia medium }\end{array}$ & $t_{o b s}$ & $P$ & $\begin{array}{l}\text { Larvae number } \\
\text { in control } \\
\text { medium }\end{array}$ & $\begin{array}{c}\text { Larvae Number } \\
\text { in Drimia } \\
\text { medium }\end{array}$ & $t_{o b s}$ & $P$ \\
\hline$\sigma^{2} \mathrm{C} \times P C$ & $19.300 \pm 2.812$ & $14.250 \pm 1.733$ & 2.721 & 0.107 & $14.200 \pm 1.607$ & $10.450 \pm 1.739$ & 0.195 & 0.661 \\
\hline$\sigma^{\prime} D . m \times$ P.$m$ & $21,400 \pm 4.300$ & $17.750 \pm 3.535$ & 2.217 & 0.145 & $2,200 \pm 0,991$ & $2,550 \pm 0.933$ & 0.127 & 0.724 \\
\hline o'C × oD.m & $6.050 \pm 1,327$ & $6.350 \pm 1,227$ & 0.073 & 0.789 & $4,700 \pm 1,659$ & $2.700 \pm 0.692$ & 4.242 & 0.046 \\
\hline o'D.m $m$ ×C & $9.650 \pm 1.595$ & $5.850 \pm 0.977$ & 4.106 & 0.050 & $2,550 \pm 0,933$ & $2,550 \pm 0,933$ & / & 1.000 \\
\hline
\end{tabular}

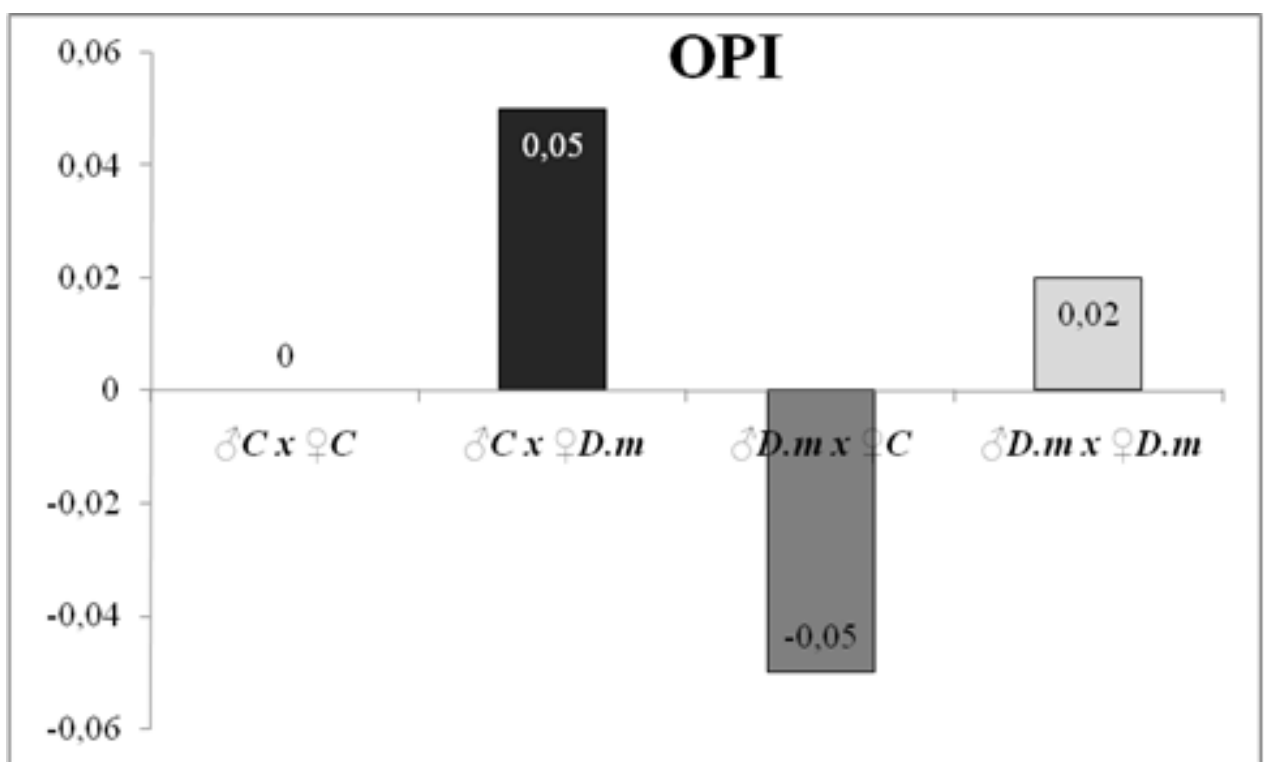

Figure 2 Oviposition preference index (OPI) of $D$. melanogaster females to $D$. maritima ethanolic extract $(0.12 \mu \mathrm{g} / \mathrm{ml})$.

Also, several studies have highlighted the toxic effect of North African aromatic plants on Diptera such as the effects of Ricinus communis and Tetraclinis articulata on mosquito larvae Culex pipiens (Linné), Aedes caspius (Pallas),
Culiseta longiareolata (Aitken) and Anopheles maculipennis (Meigen). Aouinty et al (2006) and Benhissen et al (2018) were studied the $C$. longiareolata control using Nicotiana Glauca plant. Other studies showed that plants in Maghreb 
arid areas are the most effective even against the most resistant insects such as locusts (Idrissi Hassani and Hermas 2008; Idrissi et al 1998; Idrissi Hassani 2000; Lebouz 2010; Kemassi and Oueld El-Hadj 2014) or domestic cockroaches (Masna et al 2016). A recent study by Badalamenti et al (2020) showed that Drimia plant (Asparagaceae) has insecticidal activity against adults of Stegobium paniceum (Anobiidae).

In this study, the treatment showed that D. maritima also influences the development of this Diptera since only $80 \%$ of the treated larvae reach the adult stage. D. maritima causes an acceleration in larvae growth in pupae at the three concentrations chosen; it seems that the larvae do not consume the plant treated food. Deepak et al (2003) have also mentioned that a similar plant is not consumed by either humans or animals due to its toxicity. Hence, the oral administration of Drimia indica in any form may be a matter of serious concern, and further toxicity studies are warranted before its use as an oral drug (Aswal et al 2019).

Plants of Drimia genus are known for their toxic activity in humans and mammals; in large doses, the plants mainly their bulbs, were emetic and cathartic and could cause cardiac depression (Amasta et al 1986). A classical Ayurvedic text has also revealed that although the plant bulbs control nausea and vomiting, large doses can produce vomiting and should not be used as such without processing (Sankhyadhar et al 2012). The $D$. indica bulbs causes' acute and chronic toxicity with a C-glycosyl flavone and the flavone exhibited a safety profile in toxicity experiments (Bevara et al 2017). According to Verbiscar et al (1986), the active compounds in our plant, D. maritima, are L-azetidine-2-carboxylic acid (AZA) (Hegnauer 1970), and the bufadienolides scilliroside, scilla glycoside, and aglycones. Ghorabi and Ghouana (2018) shown that only the bulb contains the main constituents which are cardiotonic heterosides (scillarenes $A$ and $B$, scillipicrin, scillin, scillitoxin). Scillarene $A$ and scillarene $B$ are two steroid cardiotonic heterosides, of the bufadienolide type. The $D$. maritima aqueous extract is composed of phenols $2.3 \%$, tannins $0.66 \%$, and flavonoids $0.1 \%$.

D. maritima leaves and bulbs exhibited significant insecticidal activity against several species (Pascual-Villalobos and Fernandez 1999; Pascual-Villalobos 2002; Metin and Burun 2010). Different active compounds with insecticidal properties including L-azatidine-2-carboxilic acid and bufadienolides, scillirosidin and proscillaridin $A$, have been isolated from this Drimia species (Hassid et al 1976; PascualVillalobos 2002).

Plants may not kill insects, but they block their reproduction. This effect type was observed in $D$. melanogaster fly after treatment with $P$. harmala (El-Bah et al 2016). The study by Habbachi et al (2019) shows that the aqueous extract of Cleome arabica (Capparidaceae) causes up to $50 \%$ mortality in Drosophila but has a significant effect on fly sexual behaviour. The bulbs of our plant act in the same way; a disturbance of the different sequences leading to adult mating is observed after the ingestion of the ethanolic extract of D.maritima.
The blockage of sexual parade or mating is especially noticeable when one of the two partners is treated; this may be due to the mutual non-recognition between the two insects especially as the plant acts significantly on the contact sequence in the fly. The contacts role in the mutual partners recognition has been demonstrated in different insect species such as cockroaches (Roth and Willis 1952; Smyth 1963; Farine et al 1993; Gropeaux 1994). One of the control means that works in better harmony with the environment is the use of plant-derived toxicants, some of which are involved in the neuroendocrine regulation, metamorphosis, and reproduction of insects (Philogene 1991; Rembold 1994). The experience of male partner selection was not simply a measure of male preference; successful copulation also requires that the target female be receptive (Somashekar et al 2011).

The sexual behaviour of males and females is influenced by pheromones. The Gr68a gene is expressed in specific neurons in the forelegs of males and is recognized as a receptor for pheromones. Inactivation of the GR68a gene results in reduced courtship performance in males (Bray and Amrein 2003). A second candidate, Gr32a, is also involved in phenomenal recognition (Miyamoto and Amrein 2008). Recently a receptors family has been described (PPKs Flybase gene family). This family constitutes a new class of pheromone receptors (Thistle et al 2012). D. maritima intake in the Tribolium castaneum diet (Coleoptera; Tenebrionidae) caused a statistically significant larvae growth inhibition and adult fertility reduction.

The eggs laid number per female was reduced if the Drimia's compounds were added to the diet. Again, Drimia's molecules (scillirosidin and proscillaridin A) were more active by completely inhibiting fertility (Pascual-Villalobos 2002). In the third part of the present study, we showed that oviposition site choice in Drosophila females (oviposition behaviour) is not modified after treatment; females can also choose the treated culture medium as an oviposition site to ensure their generations development and the "OPI" choice index confirms this result. On the other hand, D. maitima extract acts on eggs laid and larvae numbers; the larvae number decreases significantly after treatment, which indicates that $D$. martima bulbs have blocked fecundity and fertility of $D$. melanogaster. El-Bah's (2016) study indicated the same results as when using the toxic plant $P$. harmala.

\section{Conclusions}

This study indicates that D.maritima ethanolic extract has a neurotoxic property, the sublethal concentration $(0.12 \mu \mathrm{g} / \mathrm{ml})$ shows that the treated individuals are unable to present a complete nuptial coutship. Chemical analysis of treated and control flies can provide information on any changes in adults nuptial courtship, pheromone secretions, mating duration and various sexual sequences for adults. This work results suggest the presence of toxic secondary metabolites in the extract studied, which may lead to the 
development of bioinsecticides based on $D$. maritima to be used in agriculture and sold on the pesticide market.

\section{Conflict of Interest}

The authors declare that they have no conflict of interest.

\section{Funding}

This research did not receive any financial support.

\section{References}

Aliotta G, De Santo NG, Pollio A, Sepe J, Touwaide A (2004) The diuretic use of Scilla from Dioscorides to the end of the 18th century. J Nephrol 17:342347.

Amasta, S.P (1986). The Useful Plants of India, 1st ed.; CSIR: New Delhi, India. Aouinty B, Oufara S, Mellouki F, Mahari S (2006) Évaluation préliminaire de I'activité larvicide des extraits aqueux des feuilles du ricin (Ricinus communis L.) et du bois de thuya (Tetraclinis articulata (Vahl) Mast.) sur les larves de quatre moustiques culicidés : Culex pipiens (Linné), Aedes caspius (Pallas), Culiseta longiareolata (Aitken) et Anopheles maculipennis (Meigen). Biotechnologie, Agronomie, Société et Environnement 10:67-71.

Aswal S, Kumar A, Semwal RB, Chauhan A, Kumar A, Lehmann J, Semwal DK (2019) Drimia indica: A Plant Used in Traditional Medicine and Its Potential for Clinical Uses. Medicina 55:255.

Badalamenti N, Rosselli S, Zito P, Bruno M (2020) Phytochemical profile and insecticidal activity of Drimia pancration (Asparagaceae) against adults of Stegobium paniceum (Anobiidae). Natural Product Research. doi:10.1080/14786419.2020.1729154.

Badiaga M (2011) Étude ethnobotanique, phytochimique et activités biologiques de Nauclealatifolia(smith). Une plante médicinale africaine récoltée au Mali. Thèse de Doctorat, Université de Bamako 137p.

Becher PG, Flick G, Rozpędowska E, Schmidt A, Hagman A, Lebreton S et al (2012) Yeast, not fruit volatiles mediate Drosophila melanogaster attraction, oviposition and development. Functional Ecology 26:822-828.

Benhissen S, Rebbas K, Habbachi W, Masna F (2018) Bioactivity of Nicotiana glauca Graham (Solanaceae) and its toxic effects on Culiseta longiareolata (Diptera; Culicidae). International Journal of Research in Ayurveda and Pharmacy 9:123-126.

Bevara GB, Kumar AND, Koteswramma KL, Badana AK, Kumari S, Yarla NS, Malla RR (2017) C-glycosyl flavone from Urginea indica inhibits growth and dissemination of ehrlich ascites carcinoma cells in mice. Anti-Cancer Agents in Medicinal Chemistry 17:1256-1266.

Bray S, Amrein H (2003) A putative Drosophila pheromone receptor expressed in male-specific taste neurons is required for efficient courtship. Neuron 39:1019-1029.

Chardonnet F (2013) Rôle du gène foraging dans l'évolution du comportement alimentaire de noctuelles foreuses de céréales. Doctoral thesis in Biology of organisms, Pierre and Marie Curie University of Gif-surYvette, France, 245 pp.

Civelek HS, Weintraub PG (2004) Effects of Two Plant Extracts on Larval Leafminer Liriomyza trifolii (Diptera: Agromyzidae) in Tomatoes. Journal of Economic Entomology 97:1581-1586.

Clynen E, Ciudad L, Bellés X, Piulachs MD, (2011) Conservation of fruitless' role as master regulator of male courtship behaviour from cockroaches to flies. Development Genes and Evolution 221:43-48.

Corby-Harris V, Pontaroli AC, Shimkets LJ, Bennetzen JL, Habel KE, Promislow DEL (2007) Geographical Distribution and Diversity of Bacteria Associated with Natural Populations of Drosophila melanogaster. Applied and Environmental Microbiology 73:3470-3479.

Deepak AV, Thippeswamy G, Shivakameshwari MN, Salimath BP (2003) Isolation and characterization of a 29-kDa glycoprotein with antifungal activity from bulbs of Urginea indica. Biochemical and Biophysical Research Communications 311:735-742.
Dickson BJ (2008) Wired for Sex: The Neurobiology of Drosophila Mating Decisions. Science 322: 04-909.

Dobignard A, Chatelain C (2013) Index synonymique de la flore d'Afrique du Nord (vol.4) ÉDITIONS DES CONSERVATOIRE ET JARDIN BOTANIQUES Genève, p 465.

Dua VK, Pandey AC, Dash AP (2010) Adulticidal activity of essential oil of Lantana camara leaves against mosquitoes. Indian Journal of Medical Research 131:434-439.

El-Bah D, Habbachi W, Ouakid ML, Tahraoui A (2016) Sublethal effects of Peganum harmala (Zygophyllaceae) on sexual behavior and oviposition in fruit fly Drosophila melanogaster (Diptera: Drosophilidae). Journal of Entomology and Zoology Studies 4:638-642.

Farine JP, Le Quéré JL, Duffy J, Sémon E, Brossut R (1993) 4-Hydroxy 5methyl-3-(2H)-furanone and 4-hydroxy-2, 5-dimethyl-3-(2H)-furanone, two components of the male sex pheromone of Eurycotis floridana (Blattidae). Bioscience, Biotechnology, and Biochemistry 57:2026-2030.

Finney DJ (1971) Probits analysis. 3rd. Ed, Cambridge University Press. London.

Ghahreman A (1997) Flora of Iran, Vol 4. Tehran: research institute of forests and rangelands p.496.

Ghorabi A, Ghouana M (2018) Etude de l'activité antioxydante de l'extrait aqueux de deux plantes : Salvia officinalis et Drimia maritima. Mémoire, Université des Frères Mentouri Constantine 1 Faculté des Sciences de la Nature et de la Vie.

Greenspan RJ, Ferveur JF (2000) Courtship in Drosophila. Annual Review of Genetics 3:205-232.

Ghosh A, Chowdhury N, and Chandra G (2012) Plant extracts as potential mosquito larvicides. Indian Journal of Medical Research 135 581-598.

Gropeaux JC (1994) Comportement sexuel de Diploptera punctata (Dictyoptera, Blaberidae) Approche éthologique. Mémoire de diplôme d'études approfondies de Biologie, Université Paris XIII. 18 pp.

Habbachi W, Benhissen S, Ouakid ML, Farine JP (2013) Effets biologiques d'extraits aqueux de Peganum harmala (I.) (Zygophyllaceae) sur la mortalité et le développement larvaire de Drosophila melanogaster (Diptera Drosophilidae). Algerian journal of Arid Environment 3 (1) : 82-88.

Habbachi S, Amri N ; Benhissen S, Habbachi W, Rebbas K, Tahraoui A (2019) effets toxiques des extraits aqueux du cleome arabica I.(capparidaceae) sur la mortalité et le comportement sexuel de Drosophila melanogaster (diptera :drosophilidae). Journal of Animal Behaviour and Biometeorology 7:137-143. Hammiche V, Merad R, Azzouz M (2013) Plantes toxiques à usage médicinal du pourtour méditerranéen, $\mathrm{p}$ 227-231.

Hammiche V, Gueyouche R (1988) Plantes médicinales et thérapeutiques, 1ère partie Les plantes médicinales dans la vie moderne et leur situation en Algérie, Annales de I'INA El Harrach, Alger, 12:419-433.

Hassid, E, Appelbaum SW, Birk Y (1976) Azetidine- 2-carboxylic acid: a naturally occurring inhibitor of Spodoptera, littoralis (Boisd.) (Lepidoptera: Noctuidae). Phytoparasitica 4:173-183.

Hegnauer R (1970) Cardenolide and bufadienolide (cardadienolide) Spread and systematic importance. Planta Med. 19:138-153.

Idrissi Hassani LM, Ould Ahmedou ML, Chihrane J, Bouaichi A (1998) Effets d'une alimentation en Peganum harmala (Zygophyllaceae) sur la survie et le développement ovarien du criquet pèlerin Schistocerca gregaria Forskål (Orthoptera, Acrididae). Ethnopharmacologia 23:26-41.

Idrissi Hassani LM, Hermas J (2008) Effets de l'alimentation en Peganum harmala L. (Zygophyllaceae) sur le tube digestif du criquet pèlerin Schistocerca gregaria Forsk. (Orthoptera, Acrididae). Zoologica Baetica 19:71-84.

Idrissi Hassani LM (2000) Contribution à l'étude phytochimique du harmel Peganum harmala L. (Zygophyllaceae) et étude de ses effets sur la reproduction et le développement du criquet pèlerin Schistocerca gregaria Forsk. Doctoral thesis, University of Ibn Zohr, Agadir (Morocco). 214p.

Isman MB (2019) Botanical insecticides in the twenty-first century-fulfilling their promise? Annu Rev Entomol 65:111-117

Jolivet P (1980) Les insectes et I'homme. PUF, collect. Que sais-je? 128pp. 
Joly D, (2006) La drosophile : Un insecte au service de la science. Insectes, 128:25-29.

Joly A (2010) intoxication digitalique non medicamenteuse : un risque non négligeable. Doctoral thesis in medicine, université henri poincaré nancy 1 , $128 p p$.

Sukumar K, Perich MJ, Boobar LR (1991) Botanical derivatives in mosquito control: a review. Journal of American Mosquito Control Association 72:210237.

Kemassi A, Bouziane N, Boual Z, Ould El Hadj MD (2014) Activité biologique des huiles essentielles de Peganum harmala L. (Zygophyllaceae) et de Cleome arabica L. (Capparidaceae) sur Schistocerca gregaria (Forskål 1775). Phytotérapie 12:348-353.

Kloepper J, Harrison M. Brewer J (1979) The association of Erwinia carotovora var.atroseptica and Erwinia carotovora var. carotovora with insects in Colorado. American Journal of Potato Research 56:351-361.

Lebouz I (2010) Activité biologique des extraits foliaires de Cleome arabica L. (Capparidaceae) chez Schistocerca gregaria (Forskål, 1775) (Orthoptera, Acrididae). Mémoire Magistere, Universite de Biskra, 165p.

Masna $F$ (2016) Inventaire de la faune Blattoptère urbaine et forestière dans la région aride de Laghouat. Caractérisation des principales espèces nuisibles et essais de lutte. Doctoral thesis. University of Annaba (Algeria). 153p.

Meigen JW (1830) SystematischeBeschreibung der bekannteneuropäischenzweiflügeligenInsekten. 6 . Hamm.

Metin M, Burun B (2010) Effects of the High Doses of Urginea maritima (L.) Baker Extract on Chromosomes. Caryologia 63:367-375.

Miyamoto T, Amrein H (2008) Suppression of male courtship by a Drosophila pherpmone receptor. Nat. neurosic 11:874.6.

Nadarasah G, Stavrinides J (2011) Insects as alternative hosts for phytopathogenicbacteria. FEMS. Microbiol 35:555-575.

Pascual-Villalobos MJ, Fernandez M (1999) Insecticidal activity of ethanolic extracts of Urginea maritime (L.) Baker bulbs. Indust. Crops Prod 10:115-120.

Pascual-Villalobos MJ (2002) Anti-insect activity of bufadienolides from Urginea maritima. Janick and A. Whipkey p.564-566.

Philogène BJR (1991) L'utilisation des produits naturels dans la lutte contre les insectes : problèmes et perspectives La lutte anti-acridienne Ed AUPELFUREF, John Libbey Eurotext, Paris 269-278.

Quezel P (1978) Peuplement végétal des hautes montagnes de l'Afrique du nord. Encyclopédie biogéographique et écologique. Ed, Paul Lechevalier, Paris, 463p.
Rembold H (1994) Controlling locusts with plant chemicals. New Trends in Locust Control (eds. S. Krall, H. Wilps), GTZ, Eschborn, TZ-Verlagsgesellschaft Rossdorf, 41-49.

Revadi S, Lebreton S, Witzgall P, Anfora G, Dekker T, Becher PG (2015) Sexual Behavior of Drosophila suzukii. Insects 6:183-196.

Roth LM, Willis R (1952) A study of cockroach behaviour. The American Midland Naturalist 47:66-129.

Sankhyadhar SC (2012) Shri Narhari Pandit's Raj Nighantu: Chaukhamba Orientalia: Varanasi, India, 310p.

Smyth TJ (1963) Mating behavior of the Madeira cockroach. In: 35th Animal meeting eastern branch, Entomology Society of America.

Sokolowski M.B., 2001. Drosophila: genetics meets behavior. Nat. Rev. Gene 2:879-890.

Somashekar K, Krishna MS, Hegde SN, Jayaramu SC (2011) Effects of age on female reproductive success in Drosophila bipectinata. Journal of Insect Science 11:1536-2442.

Stannard J (1974) Squill in ancient and medieval materiamedi-ca, with special reference to its employment for dropsy. J Urban Health 50:684-713.

Stoll A (1954) Sur les substances cardiotoniques de la scille maritime (Scillamaritima L): Cardiotonic Substances of scillamaririma. Experientia 10:282-297.

Subramaniam J, Kovendan K, Mahesh Kumar P, Murugan K, Walton W (2012) Mosquito larvicidal activity of Aloe vera (Family: Liliaceae) leaf extract and Bacillus sphaericus, against Chikungunya vector, Aedes aegypti. Saudi Journal of Biological Sciences 19:503-509.

Terhzaz S (2003) Caractérisation de deux neuropeptides chez Drosophila melanogaster: Ialeucokinine et l'IFamide. Doctoral thesis in Neurosciences and Neuropharmacology, University of Bordeaux I, France, 211p.

Thistle R, Cameron P, Ghorayshi A, Dennison L, Scott K (2012) Contact Chemoreceptors Mediate Male-Male Repulsion and Male-Female Attraction during Drosophila Courtship. Cell 149:1140-1151.

Verbiscar AJ, Patel J, Banigan TF, Schatz RA (1986) Scilliroside and other scilla compounds in red squill. Journal of Agricultural and Food Chemistry 34:973979.

Zargari A (1996) Medicinal plants. Vol 3. Tehran: Tehran University Publications, pp 513-514. 